\title{
The Oldest Hebrew Document in Poland (1485) AND ITS TRANSLATIONS
}

\author{
Marcin Starzyński \\ (Jagiellonian University, Kraków) \\ e-mail: starzynski@ymail.com
}

Key words: medieval Kraków, Jews in medieval Poland, medieval trade, Hebrew diplomatics

\begin{abstract}
The following article presents the content and the context of issuing of the oldest Hebrew document preserved in Poland, written in Kraków in 1485. Having analysed the history of the Kraków Kahal in the second half of the $15^{\text {th }}$ century and trade politics conducted by large town centres in the Kingdom of Poland, the author relates this document to the activities conducted by the royal burgesses. These activities were to lead to a restriction of the rights of merchants-guests (hospites), and consequently the rights of the Jewish merchants. The text of the document (with a Polish translation) and its translations into Latin and German made in 1492 are included in an appendix.
\end{abstract}

At the beginning of the last century, scholars attempting pioneering studies of the earliest history of the Jewish religious community in Kraków still had access to primary sources that are now preserved only in photographs, written copies made at the time, or references in the literature. Among these were fragments of a memmorbuch dated to the fourteenth century, once kept in the Kupa Synagogue but now believed to be lost. It has since been identified as a siddur (Heb. sid $[d] u r$, Yid. sider) — a prayer book containing a complete set of daily and Sabbath prayers. ${ }^{1}$ An anonymous glossator annotated a prayer for the ruler ("Let the Almighty, who hath given kings and rulers strength and power to rule [...] bless, preserve, and exalt him, whose realm is exalted") writing that one should remember the Polish King Casimir in supplications to God ("and so is our most merciful and most gracious King Casimir, may his majesty be long exalted"). ${ }^{2}$ A richly illuminated, fourteenth-century bible, most likely produced in Regensburg, was also known to historians. It most probably did not appear in Kraków until the nineteenth century and

${ }^{1}$ During a discussion of the present text, which took place during a session of the Komisja Historii i Kultury Żydów (Commission on Jewish Culture and History) at the Polska Akademia Umiejętności (Polish Academy of Arts and Sciences) on June 14, 2017, Dr. hab. Leszek Hońdo of the Institute of Jewish Studies at the Jagiellonian University proposed a new identification for this historical document.

Cf. Müller 1906, cit.: 52, fig. I-II. Zaremska 2011: 26-27 who, based on the opinion of Abraham David of the Department of Hebrew Manuscripts at the National Library of Israel, dated both the text of the prayer and the handwritten gloss to the fifteenth century. In accordance with this interpretation, the reference to King Casimir would have to refer to Casimir IV.

${ }^{2}$ Müller 1906: 52. 
was initially preserved in the Old Synagogue, and then in the seat of the Jewish Religious Community of the City of Kraków. ${ }^{3}$ At the end of the nineteenth century, Feivel Hirsch Wettstein, a scholar of Jewish "antiquity" and owner of a second-hand bookstore at Szpitalna (Hospitalis) Street in Kraków, published a note from a Kraków pinkas, a record book kept by the Community, dated 1494. It reads, "testimony concerning a debt of 100 Hungarian ducats, a very interesting arrangement between Kraków melameds." " Izaak Planer, who was working on a review of a different publication of Wettstein, discovered in Aaron Faust's bookstore a pinkas composed of loose folios containing documents from the years 1582-1657. ${ }^{5}$ However, when Majer Bałaban was writing his monumental history of the Jews of Kraków and Kazimierz before 1912, he still had access to the statute of the kahal from $1595,{ }^{6}$ but he dated the earliest records in the pinakse $i$ that he studied to $1603 .^{7}$ Bałaban reconstructed the history of the medieval period, working almost entirely from Christian sources; however, he knew of one Hebrew document composed in the Kraków community, undated but correctly linked to 1485, which concerned the regulation of Jewish retail trade in Kraków. ${ }^{8}$ In spite of recently intensified efforts on cataloguing and accurately identifying medieval Hebraica preserved in manuscript bindings in Kraków archives and libraries, no new written sources on the life of the Kraków community, or more importantly, produced by the community, have been found. A noteworthy example of these efforts is the project "Books within Books: Hebrew Fragments in European Libraries" headed by Judith Olszowy-Schlanger, under whose auspices one hundred and nine codices containing fragments of Hebrew manuscripts have been identified in the collections of the Jagiellonian Library. Most of the fragments come from liturgical or legal sources, including fragments of the fourteenth-century account book of a Provençal moneylender, considered very rare in the broader European context. ${ }^{9}$ Further, a fragment of a Hebrew Bible (the Book of Ezekiel) that in the late fifteenth century had been used in the binding of a manuscript containing, among others, the calendar of the altarists' house of Saint Mary's Church in Kraków, has been discovered in the collections of the National Archives. ${ }^{10}$

The priceless and unique source document that is the subject of the present article was, as mentioned earlier, known to historians of the Kraków Jewish community, yet until now had not been thoroughly analyzed or published in a contemporary edition. Also

3 Ameisenowa 1929: 16-19.

${ }^{4}$ See: Wettstein 1892; Bałaban 1903: 477.

${ }^{5}$ Planer 1903: 127, n. 1.

${ }^{6}$ Bałaban 1912: 299-308 (detailed description of the codex); Polish translation: Jakimyszyn 2005.

${ }^{7}$ Bałaban 1931: 561.

${ }^{8}$ Ibid.: 60, n. 6; photograph follows: 114 .

${ }^{9}$ Olszowy-Schlanger 2014a: 156-158; Olszowy-Schlanger 2014b: 97-147 (with the editon).

${ }_{10}$ The National Archives in Krakow (hereafter: ANK), MS no. 3361. The binding of the manuscript has recently been reproduced in Zaremska 2011: 58, fig. 5. The caption is incorrect, however. The pages of Hebrew text come from a mahzor (prayer book) imported from Germany sometime in the thirteenth or fourteenth century. Elsewhere, the author writes that the fragments are from a "prayer for the dead, glued into the binding of a manuscript containing texts relating to the altarists' house of Saint Mary's Basilica in Kraków" (ibid.: 27). This information also appeared in the German edition: Zaremska 2013. In fact, the text fragments come from the Book of Ezekiel: front cover backing, right column Ez 27:19-21, center column Ez 29:27-30, left Ez 28,2; back cover backing, right column and illegible text in the upper portion of the center column Ex 27:22-25, left column Ex 27:30-33, see: Starzyński (forthcoming). 
omitted from the literature has been the fact that since the Middle Ages, the document has been kept with three others in a custom-made parchment envelope, initially with a diploma issued by Kraków voivode Jan Amor of Tarnów on June 7, 1485. In 1492, these documents were joined by two unauthenticated translations of the Hebrew text into Latin and German. ${ }^{11}$ In analyzing this document, the chancellery context cannot be ignored.

Two of the documents mentioned above (the Latin translation of the Hebrew diploma dated to approximately June 1485, and the document issued by Jan Amor of Tarnów) were introduced into the literature by Franciszek Piekosiński, who published the texts in 1879 in the Codex diplomaticus civitatis Cracoviensis (Diplomatic Codex of the City of Kraków). ${ }^{12}$ It should be noted, however, that this otherwise superb editor of primary sources did not look to the originals, which at the time were known to be housed in the Archives of Historical Records of the City of Kraków. Instead, he relied upon later seventeenth-century copies preserved in the so-called Kodeks Zaleskiego (Zaleski Codex). ${ }^{13}$ Most likely the first scholar to uncover the Hebrew original was Feivel Hirsch Wettstein in about 1901. He published both the Hebrew text and the German translation, but did not provide bibliographical information. ${ }^{14}$ The documents are not mentioned in the printed catalogue of the Archives of Historical Records of the City of Kraków from 1907, because it only includes documents on parchment. ${ }^{15}$ Eugeniusz Müller made use of Piekosiński's publication, but his interpretation was not entirely correct. ${ }^{16}$ Majer Bałaban also accessed the Hebrew original and in 1912 published the first photograph of the document. ${ }^{17}$ Ignacy Schipper was also aware of the document's existence. ${ }^{18}$ In the more recent literature, Bożena Wyrozumska ${ }^{19}$ and Hanna Zaremska ${ }^{20}$ discuss the document in greater detail. However, several years ago Judith Olszowy-Schlanger conceded that it was lost. ${ }^{21}$ Since the originals of all four documents in their parchment envelope are preserved in the National Archives in Kraków, it has become imperative to publish all four in a critical edition based, for the first time, on a reading of the authentic texts, with pertinent commentary which would sum up earlier research on this unique written relic.

The reasons for which the titular document from 1485 was issued are not and, I suspect, will never be fully understood. We can, however, attempt to place the diploma within the historical context - against a background of actions taken by the Crown's burghers in several important trading centers to limit the rights of guest merchants. They intended to incorporate Jewish merchants into this group.

${ }^{11}$ ANK, MS no. 658/1248-1251.

12 Piekosiński 1879, nos. 192-193.

${ }^{13}$ ANK, MS no. 1449: Codex iurium et privilegiorum urbis metropolis Cracoviensis of 1694.

${ }_{14}$ Wettstein 1901: I-II.

${ }^{15}$ Krzyżanowski 1907.

16 Müller 1906: 19-20.

17 Bałaban 1931, vol. 1: 59-61, fig. follows: 114.

18 Schipper 1911: 192-193.

19 Wyrozumska 1993: 7-8.

${ }^{20}$ Zaremska 2011: 208-209, 214.

${ }^{21}$ Olszowy-Schlanger 2014a: 155. In addition, she wrote that "there are very few known documents relating to medieval Krakow" (ibid.: 154). To put it more precisely, there is only one document. 
There is little evidence of specific tensions between the city authorities, the local merchants, and the Jewish community in the extant sources from the period immediately preceding the event (in this case, primarily municipal court records). In January 1469, the community leaders (seniores Judei), Mojżesz, Jakub, Nacham, Abraham of Sącz, and Jakub Nol, together with the Jewish judge Jan Chamiec of Dobranowice and another Jan, a notary and sub-judge (Lat. subiudex) signed an agreement with the Długosz brothers, the chronicler Jan the Elder and Jan the Younger, both Kraków canons. Under this they relinquished land owned by the Jewish community at Żydowska Street (Platea Judeorum), where there were two synagogues (one old, one new), hospitals, and a cemetery (behind the Collegium Maius and near the house of Jan of Tęczyn, the castellan of Kraków), in exchange for land at Szpiglarska Street, behind the Church of Saint Stephen, on which there already stood a synagogue. The value of this site was assessed at 200 sexagenae Prague groschen. It should be added that the text of the certificate was copied de verbo ad verbum [...] de libro iuris Judaici, in other words the community's pinkas, which has not been noted in the extant literature. ${ }^{22}$ In reconstructing the medieval history of the Kraków Jewish community, Majer Bałaban wrote rather emotionally that “the Jews' move to Szpiglarska Street (Saint Stephen's Square) was practically tantamount to exile." ${ }^{23}$ We now know that this was a planned move, since a number of real estate deals had already taken place in the period from 1467 to 1468, with Jews selling their properties on Garncarska Street (now Gołębia Street) and buying property on Szpiglarska Street. Particularly notable is the purchase of a house on Szpiglarska Street in April 1468 by Michil Baroch, who made the purchase in the name of ganczen gemeynne der Juden, and also pledged not to sell it to the city without the community's agreement. ${ }^{24}$ "It is not known whether the house was meant to be used by the community for public purposes or what the other reasons there may have been for this proviso." 25 Speculations as to whether or not the move of 1469 came about because of "blackmail" on the part of the municipal authorities and was in fact a concession on the part of the Jewish community against the possibility that limitations on Jewish trade would be introduced must, however, remain in the realm of conjecture. ${ }^{26}$ What is certain is that in 1477, a number of incidents of looting of Jewish property occurred in conjunction with a fire, but these do not appear to have been widespread. ${ }^{27}$ However, the lack of records of real estate transactions from the last quarter of the fifteenth century (acta scabinalia) obscures Christian-Jewish relations in Krakow in about $1485 .{ }^{28}$ The possibility that city hall already had information about two interesting privileges relating to the status of socalled foreign merchants before talks between the elders of the Kraków Kahal and city council began cannot be ruled out. In March of 1483, at the request of the authorities of the Old Town of Warsaw for which they laid out the lofty sum of 120 gold Hungarian florins, the Mazovian Duke Bolesław V of Warsaw issued a document which, among other things, granted a license to sell beer from Warka in the cellars of the town hall,

\footnotetext{
22 CDUJ 1873, no. 223; Wyrozumski 2010: 302.

23 Bałaban 1931, vol. 1: 58.

24 Wyrozumska 1995a, no. 512; Zaremska 2011: 359-361, 364-365; Niemiec 2013: 50-52.

25 Wyrozumski 2010: 302.

26 Zaremska 2011: 360.

27 Wyrozumska 1995a, no. 572: pro infamia furti ex Judeis tempore ignis viventis.

28 Wyrozumska 1995b: 69.
} 
greatly limiting the rights of guest merchants. They could no longer engage in retail trade (tales nonnisi integre in stucis, staminibus, lapidibus res suas quascunque et merces vendendi habeant facultatem) ${ }^{29}$ Although the Jews were not mentioned in this document per se, "undoubtedly some of its resolutions affected them." ${ }^{30}$ Another significant text in this context, possibly more important than the one discussed above, is the document that king Casimir IV issued at the Lublin Sejm in February of 1484 (no doubt closely watched by representatives from Kraków), which concerned Armenian and Jewish merchants. In response to a grievance brought by the burghers of Lwów, the king appealed to the officials of Ruthenia and Podolia to see to it that the Lwów staple rights were respected, especially by the Jews and Armenians, who would sell goods in smaller towns. The goods of merchants caught selling outside of Lwów were to be confiscated for the royal treasury. ${ }^{31}$

In the summer of 1485 , the Kraków Jews, possibly somehow "blackmailed" by city officials, agreed to significant limitations on their retail trade in the city. Probably also at the request of the council, the community scribe prepared a separate document, which then was deposited in the town hall "for proof and testimony." It was written on a fairly small sheet of paper (w. $218 \times$ h. $162 \mathrm{~mm}$ ) in the calligraphic Ashkenazi writing characteristic of the fifteenth century, which also speaks to the significance of the document. The elders of the community, Mojżesz, son of Efraim Fiszl; his brother Józef; Jakub, son of Aleksander; and Mordechaj, son of Jakub, agreed on behalf of the entire kahal that henceforth Kraków's Jews would not participate in retail trade (with Christians). The only exception to this was for holders of objects left as security for loans that had not been redeemed on time (so-called lapsed bonds - obligatio sub lapsu), which they could sell, but only in their own homes; they could engage in public trade only on Tuesdays and Fridays (market days) and during the fairs that took place in Kraków three times per year-for the Feast of the Cross in May, the Feast of Saint Barnabas in June, and the Feast of Saint Michael (Michaelmas) in September. ${ }^{32}$ The condition sine qua non was that a solemn oath be sworn (one of two key means of evidence under Jewish law) that a given object was forfeited collateral. If, however, a Jew were to be found selling goods outside of the terms outlined above, the goods could be confiscated. The dealer faced imprisonment in the town hall jail until he paid a fine of three marcarum to the voivode. ${ }^{33}$ Poor (Jewish) women, however, were permitted to sell caps and collars that they made themselves. This rather drastic-sounding agreement, signed by the above four elders, was deposited, as noted earlier, at the Kraków town hall and undoubtedly, most likely due to the language barrier, must have been treated as an object of quasi-magical significance - it was obviously legally binding, but was in fact incomprehensible to a Gentile reader ${ }^{34}$ This document most likely reached the authorities together with the document confirming the regulations issued by the voivode, who had legal authority over the Jewish population of Małopolska (Lesser Poland), but not together with the

\footnotetext{
29 Wierzbowski 1913, no. 21; Zaremska 2011: 209-210.

30 Zaremska 2011: 209.

31 AGZ 1878, no. 74; Zaremska 2011: 210.

32 Wyrozumski 1992: 390.

33 A fine in the same amount was already noted in the Charter of Jewish Liberties ratified by Casimir IV in 1453, but repealed during the Nieszawa diet, in the paragraph regulating issues of insubordination to superiors, see: Ulanowski 1897: 102, art. XI: De pene rebellionis Judeorum; Zaremska 2011: 372-373.

34 Jurek 2002: 13-14.
} 
Latin translation, as Majer Bałaban supposed..$^{35}$ It is possible that a second copy of the voivode's diploma was deposited in the kahal's archives. Most probably, however, its resolutions never actually took effect. ${ }^{36}$ It would appear that the fact that a Hebrew diploma was issued and reiterated by the tenor of the voivode's document was more likely a show of force on the part of the city authorities than an actual introduction of restrictions, which would in fact have driven the Jews out of all arenas of the commercial life of the city. It also clearly fit into the politics of the Kraków authorities at the time. Seen in a somewhat broader context, the problem reflects the desire of late-fifteenth century Polish burghers in larger mercantile centers to gradually restrict the prerogatives of the so-called hospites. This process should not, however, be perceived in any way as a coordinated move on the part of the burghers of the Polish Crown, but rather as the isolated actions of municipal authorities looking out for the interests of particular communities. What has gone unnoted in the literature is that a week after the voivode's document was issued, Casimir IV confirmed the earlier privilege of the city of Kraków's right to collect a duty on cloth brought into the city by merchants who were not citizens. ${ }^{37}$ On the same day, the king also decreed that merchants from Breslau on their way to Ruthenia could not circumvent Kraków's staple rights. ${ }^{38}$ Certainly, the issuance of these documents was not instigated by the king, but was the result of often informal lobbying by the municipal authorities. ${ }^{39}$ Within the context presented here, it would be difficult not to mention the ruling of Jan Olbracht, royal governor of Ruthenia from 1486, on the wellknown legal dispute between the Lwów merchants (Christian) and Jewish merchants about the retail sale of cloth. The Lwów authorities held that the city's Jewish merchants should be subject to the same regulations as merchants in other cities in the Kingdom of Poland-Kraków, Poznan, and Sandomierz-where they were forbidden to engage in retail trade. No documents on this subject from Poznań and Sandomierz are presently known. As to Kraków, we can speculate that the Lwów burghers knew about the diploma issued by Jan Amor of Tarnów. Prince Olbracht ruled in favor of the Lwów authorities. ${ }^{40}$ Hanna Zaremska correctly points out that some of the documents referred to above were intended to place the Jews in a rather broad category of hospites, "who were not subject to the law and jurisdiction of the cities and not bound by the precepts of city trade," ergo to change their social status. ${ }^{41}$

Majer Bałaban, whose narration takes a rather subjective turn, believed that "the Jewish elders went to city hall to publicly relinquish their human rights, i.e. their right to earn an honest living." 42 According to him, the Jews' circumvention of the decree of 1485, was supposed to lead to numerous confiscations of goods and even trigger unrest. It was around that time, in 1492, that the city authorities were supposed to have had the Hebrew document translated into German, so that it could be proclaimed about the city

\footnotetext{
35 Bałaban 1931, vol. 1: 60.

36 The first to infer this was Schipper 1911: 194.

37 Piekosiński 1879, n. 194.

38 Ibid., no. 195.

39 See: Starzyński 2010: 163-166.

40 AGZ 1878, no. 89; Zaremska 2011: 211.

41 Zaremska 2011: 211-212.

42 Bałaban 1931, vol. 1: 61.
} 
"so that every merchant and craftsman would know it." 43 However, his conclusions are not supported by primary sources. The Krakow chancellery did in fact have the document translated in 1492 into Latin and German, but as the translated documents were not authenticated, they were most likely intended for internal use. Perhaps this had something to do with the accession to the throne of the new monarch, or it was a question of the languages known and used by the city authorities. Several years later, the notary Jan Heydeke wrote in his preface to the report on the regular income of the municipality written in Latin, that the main text of this legal aid was given in German so that all of the members of the city council could understand it. ${ }^{44}$

The translations of the document that is the focus of this article were prepared by a person or persons fluent in Hebrew (an anonymous convert?) and differ slightly in form, which results from the chancellery practice used. In comparing the texts, we should focus on several terms that appear in the Hebrew original and how they are translated. To begin with, the term "leaders" (rashim) of the "sacred community" (kehilah kedoshah) was translated as the synonymous "elders" (seniores/eldsten). This term already appears in Latin sources in Polish territory in the thirteenth century, ${ }^{45}$ but in cities subject to German law it applies to either elder councilors (those did not sit on the council in a given year, but continued to have a say in municipal politics), or to elder guild members. All of the "men of the kahal" agreed to the regulations. The term kahal can refer to the community council (usually fourteen members) as well as the community itself. The translations simplify the correct interpretation of the term by employing communitas/gemene, meaning all of the citizens of the community.

What is interesting from a diplomatic point of view, is the phrase about sealing the document with signatures (cum sigillo manus nostre proprie/mit zigel unserer hantschrifft), thereby giving it legal status, which was unknown in Christian diplomacy of the period. Legal status was conferred on a document by impressing it with a seal or attaching a hanging seal to the sheet. ${ }^{46}$

The translations differ from the Hebrew text in at least three places. In the first place, in both translations the clients of the Jewish merchants are described as Christians (christianis), whereas in the original they are called goyim - non-Jews. Secondly, the translations and the original diverge on the geography of trade. In the original, only city market squares (beshukim) are mentioned, while in the other two documents the definition is expanded to market squares circa civitatem. Thirdly, we should take a look at the Jews' oath relating to the sale of pawned items. The Latin and German versions only state that it is an oath sworn on the Ten Commandments (ad Decem Precepta/uff dy Czechen Gebot). In the Hebrew text, however, there is a clear reference to an oath of the Torah on the Ten Commandments. Oaths such as this were sworn in the synagogue (the Christian court was informed of them by the local melamed). The person taking the oath wore a tallit (indutus clamide) on his shoulders and on his head a hat (pileum Judaicum) - not in

43 Ibid: : 61-62.

${ }^{44}$ Starzyński 2009: 3-4.

${ }^{45}$ KDW 1877, no. 574: Judeis senioribus Kalissiensibus; Zaremska 2011: 372.

${ }^{46}$ Zaremska 2011: 377, argues that "no mention of sealing the document to give it legal status is made in the Hebrew version because the seal was attached to the document." She may have based her conclusion on not entirely correct translation of the Latin text (testificamus cum sigillo manus nostre proprie) "we certify with the seal, with our own hands" (ibid:: 376). 
the sense of signum infamiae. In addition, at the moment of taking the iuramentum, the person's face should be turned towards the east and he should stand barefoot on a chair (verti contra solem seorsum et stare nudipes supra unam sedem). ${ }^{47}$ Furthermore, the oath was sworn on the Torah scroll removed from the Aron Kodesh, or holy ark, and covered with black cloth. Often, too, the ceremony included elements of humiliation, but no information about these has survived in Polish sources. ${ }^{48}$

Also worth noting are the names of the clothing accessories manufactured by poor Jewish women: mitznefet and anakim, which are translated as pepla et colliria/habwe und colner, that is bonnets and necklaces/collars. The elements of dress described in the document should not be linked to the those characteristic of the dress of Jewish women, the binda (Yid. shterntikhl), a woven band decorated with precious stones worn by married women at the front of the head over the bonnet (certainly in use in the late sixteenth century) and a bodice, or velvet sash tied at the neck. ${ }^{49}$ The clients for these goods must have been primarily Christian women.

In 1494, the kahal authorities and some of the members of the community moved from Kraków to Kazimierz, which is characteristically referred to in city records as locacio, meaning not only the establishment of a new community, but also the relocation of an existing community. ${ }^{50}$ The Jews did not, however, disappear from Kraków. They continued to rent stores and run businesses. Neither the document of 1485, nor its confirmation by voivode Jan Amor Tarnowski, kept together in a parchment envelope in the city hall archives, were, it would appear, considered to be particularly significant, since they were not included in the new city cartulary, more widely known as the Behem Codex, compiled at the beginning of the sixteenth century. However, references were sometimes made to the regulations, as in the privilege of Sigismund I of June 7, 1533, which regulated, among other things, issues concerning trade conducted by the Jews of Kraków or those living in Kazimierz, when the provisions of the diploma of voivode Jan Amor were considered binding. ${ }^{51}$ At the end of the seventeenth century they were incorporated to the collection of urban privileges compiled by Jan Zygmunt Zaleski. ${ }^{52}$ Even as late as 1797, in the new political reality, the new authorities of Kraków submitted the document the governor Western Galicia ${ }^{53}$ for approval. It seems, however, that his resolutions were nothing more than a reminiscence of a reality long past, rather than an actual tool to be invoked in disputes between the city and its Jewish population. Three hundred years earlier, they were perfectly in line with the policy of the authorities of some urban centers,

47 Ulanowski 1897: 111.

48 Zaremska 1999: 229-243, esp. 237-240, see also: Cohn 2007: 362; Levitats 2007: 364-365.

49 Turnau 1987: 101-108.

50 Starzyński 2015: 93-97 (in which older literature is discussed).

51 The text of this diploma suggests that the voivode's document came earlier chronologically, was accepted by the kahal elders and subsequently signed: iuxta ordinacionem et constitucionem magnifici olim Joannis Amor de Tharnow palatini Cracouiensis, quam ipsi illo tempore suapte sponte susceperant, et cui seniores illorum, ui protunc fuerant, se characteribus Judaicis subscripserant, see: Piekosiński 1885: 52 , 33.

52 ANK, MS no. 1449, f. 56v-57r.

53 Bałaban 1931: 61. 
defending the interests of their own merchants, aimed at pushing Jewish merchants out of the retail trade by lumping them in with guest/foreign merchants. Once servi camere, "servants of the treasury," subject directly to the king, they were meant to become extranei, "excluded."

Translated by Sabina Potaczek-Jasionowicz

\section{BIBLIOGRAPHY}

AGZ (1878), Akta grodzkie i ziemskie z czasów Rzeczypospolitej Polskiej z Archiwum tak zwanego bernardyńskiego we Lwowie, vol. 7, Lwów.

Ameisenowa, Z. (1929), Biblia hebrajska XIV-go wieku w Krakowie i jej dekoracja malarska, Kraków. Bałaban, M. (1903), Przegląd literatury historyi Żydów w Polsce, Kwartalnik Historyczny 17: 475-486.

Bałaban, M. (1912), Die Krakauer Judengemeinde-Ordnung von 1595 und ihre Nachträge, Jahrbuch der Jüdisch-Literarischen Gesellschaft, 2: 296-360.

Bałaban, M. (1924), Felwel Hirsz Wetstein, Nowe Życie 1: 435-437.

Bałaban, M. (1931), Historja Żydów w Krakowie i na Kazimierzu 1304-1868, vol. 1: 1304-1655, $2^{\text {nd }}$ ed., Kraków.

CDUJ (1873), Codex diplomaticus Universitatis Studii Generalis Cracoviensis, vol. 2, Cracoviae.

Cohn, H.H. (2007), Juramentum Judaeorum, more Judaico (The Jewry Oath), in: F. Skolnik (ed.), Encyclopedia Judaica, $2^{\text {nd }}$ ed., Detroit et al.: 362.

Jakimyszyn, A. (ed.) (2005), Statut krakowskiej gminy żydowskiej z roku 1595 i jego uzupetnienia. Ttumaczenie sporzadzone na podstawie odpisu Majera Bałabana, Kraków.

Jurek, T. (2002), Stanowisko dokumentu w średniowiecznej Polsce, Studia Źródłoznawcze, 40: 1-18.

KDW (1877), Kodeks dyplomatyczny Wielkopolski, vol. 1, [ed. I. Zakrzewski], Poznań.

Krzyżanowski, S. (1907), Katalog Archiwum Aktów Dawnych Miasta Krakowa, vol. 1: Dokumenty, Kraków.

Levitats, I. (2007), Oath more Judaico, in: F. Skolnik (ed.), Encyclopedia Judaica, $2^{\text {nd }}$ ed., Detroit et al: 364-365.

Müller, E. (1906), Żydzi w Krakowie w drugiej połowie XIV stulecia, Biblioteka Krakowska, vol. 35, Kraków.

Niemiec, D. (2013), Siedziby żydowskie w średniowiecznym Krakowie, in: Cracovia Judaeorum 3D. Katalog wystawy, Kraków: 41-56.

Olszowy-Schlanger, J. (2014a), Fragmenty rękopisów hebrajskich w Bibliotece Jagiellońskiej i ich znaczenie, in: S. Gąsiorowski (ed.), Studia żydowskie w Polsce - przeszłość, stan obecny, perspektywy. Studium selektywne, Polska Akademia Umiejętności. Prace Komisji Historii i Kultury Żydów, vol. 6, Kraków: 154-164.

Olszowy-Schlanger, J. (2014b), Binding Accounts. A Leger of a Jewish Pawn Broker from $14^{\text {th }}$ Century Southern France (MS Kraków, BJ Przyb/163/92), in: A. Lehnardt, J. Olszowy-Schlanger (eds.), Books within Books. New Discoveries in Old Book Bindings, Leiden-Boston: 97-148.

Piekosiński, F. (1879), Kodeks dyplomatyczny miasta Krakowa, cz. 1: 1257-1506, wyd., Monumenta Medii Aevi Historica Res Gestas Poloniae Illustrantia, vol. 5, Kraków.

Piekosiński, F. (1885), Prawa, przywileje i statuta miasta Krakowa (1507-1795), vol. 1: 1507-1586, z. 1, wyd., Acta Historia Res Gestas Poloniae Illustrantia ab Anno 1507 usque ad Annum 1795, vol. 8, Kraków.

Planer, I. (1892), [rec.:] Feivel Hirsch Wettstein, Kadmoniyot mi-pinkesa'ot Yeshanim: le-korot Yiśra'el be-Folin bi-khelal uvi-Kraka bi-ferat = Quellenschriften zur Geschichte der Juden in Polen, insbesondere in Kraków [1892], Kwartalnik Historyczny, 17: 123-130. 
Schipper, I. (1911), Studya nad stosunkami gospodarczymi Żydów w Polsce podczas średniowiecza, Monografie z Historyi Żydów w Polsce, vol. 4, Lwów.

Starzyński, M. (2009), Jan Heydeke, Census civitatis conscripti. Spis dochodów miasta Krakowa z 1500 roku ze zbiorów Archiwum Państwowego w Krakowie, wyd., Cracovienses Fontes Minores, vol. 2, Kraków.

Starzyński, M. (2010), Krakowska rada miejska w średniowieczu, Maiestas, Potestas, Communitas, vol. 3, Kraków.

Starzyński, M. (2015), Średniowieczny Kazimierz, jego ustrój i kancelaria, Kraków.

Starzyński, M. (in print), Opis rękopisu nr 3361, in: B. Wyrozumska (ed.), Kalendarz domu altarystów kościoła Mariackiego w Krakowie.

Turnau, I. (1987), Ubiór żydowski w Polsce XVI-XVIII wieku, Przeglad Orientalistyczny 3: 297-311.

Ulanowski, B. (1897), Najdawniejszy uktad systematycznego prawa polskiego z XV wieku, wyd., Archiwum Komisyi Prawniczej, vol. 5, Kraków.

Wettstein, F.H. (1892), Devarim 'atikim: mi-pinkese ha-kahal be-Kraka le-korot Yiśra'el va-hakhamav, rabanav u-manhigav be-Polanya bi-khelal uve-Kraka bi-ferat = Materialen zur Geschichte der Juden in Polen, insbesondere in Krakau, Krakau.

Wettstein, F.H. (1901), Mi-pinkase ha-kahal be-Kraka: le-korot Yiśra'el va-hakhamav, rabanav u-manhigav be-Polania bi-khelal uve-Kraka bi-ferat, Bresloia.

Wierzbowski, T. (1913), Przywileje królewskiego miasta stołecznego Starej Warszawy 1376-1772, Warszawa.

Wyrozumska, B. (1993), Czy Jan Olbracht wygnał Żydów z Krakowa?, Rocznik Krakowski 59: 5-11.

Wyrozumska, B. (1995a), Żydzi w średniowiecznym Krakowie. Wypisy źródłowe z ksiąg miejskich krakowskich / The Jews in Mediaeval Cracow. Selected Records from Cracow Municipal Books, Kraków.

Wyrozumska, B. (1995b), Kancelaria miasta Krakowa w średniowieczu, Kraków.

Wyrozumski, J. (1992), Kraków do schyłku wieków średnich, Dzieje Krakowa, vol. 1, J. Bieniarzówna, J.M. Małecki (eds.), Kraków.

Wyrozumski, J. (2010), Nowe materiały do dziejów Żydów krakowskich w średniowieczu, in: idem, Cracovia mediaevalis, M. Starzyński (ed.), Kraków (with B. Wyrozumska): 291-310.

Zaremska, H. (1999), Iuramentum Iudeorum - żydowska przysięga w średniowiecznej Polsce, in: E scientia et amicitia. Studia poświęcone Profesorowi Edwardowi Potkowskiemu w sześćdziesięciopięciolecie urodzin i czterdziestolecie pracy naukowej, Warszawa-Pułtusk: 229-243.

Zaremska, H. (2011), Żydzi w średniowiecznej Polsce. Gmina krakowska, Warszawa.

Zaremska, H. (2013), Juden in mittelalterlichen Polen und die Krakauer Judengemeinde, Klio in Polen, Bd. 17, Osnabrück. 
The elders of the Kraków Kahal hereby declare in the name of the entire community, that henceforth the Kraków Jews will not participate in retail trade in the city, with the exception of selling unredeemed pawned property following strictly defined terms and conditions, and clothing accessories made by hand by poor women-Hebrew text.

Or.: Kraków, Archiwum Narodowe [The Nationial Archives in Krakow] (hereafter: ANK), MS no. 658/1249; paper document measuring: $218 \times 162 \mathrm{~mm}$; on the reverse in contemporary hand: Littera Hebraica Judeorum.

Pub.: F.H. Wettstein, Mi-pinkase ha-kahal be-Kraka: le-korot Yiśra'el va-hakhamav, rabanav u-manhigav be-Polania bi-khelal uve-Kraka bi-ferat, Bresloia [1901-after: M. Bałaban, Felwel Hirsz Wetstein, „Nowe Życie” 1, 1924, pp. 435-437], pp. I-II (of the original).

Photo: M. Bałaban, Historja Żydów w Krakowie i na Kazimierzu 1304-1868, vol. 1: 1304-1655, $2^{\text {nd }}$ ed., Kraków 1931, photo follows p. 114.

1 נחנו החתומי מטה ראשי ק"ק דקראקוב מודים ומעידים בחתימת ידינו איך שבהסכמת כל אנשי הקהל נתרצינו

וקבלנו עלינו ברצון

2 נפשינו בלי שום אונס כלל שלא להתעסק בשום סחורה וכל עניינו סחורה או פרגמטיא נחדל ונעזוב לגמרי. גם

לא נוכל לקחת מיני

3 סחורה או פרגמטיא מסוחרים למוכרן על ידינו לגוים אחרים. זולתי המשכונות שלנו אשר כבר עבר זמנם

ונפסדו בריבית נוכל

4 למוכרם בבתינו בכל עת שיזדמן. ואותם המשכונות לא נהיה ראשים לישא ולטלטל למוכרם ברחובות ובשווקים

בתוך העיר

* I am very grateful to Dr. Anna Jakimyszyn-Gadocha and Dr. hab. Maciej Tomal of the Institute of Jewish Studies of the Jagiellonian University for their help with editing and translating the Hebrew document and for numerous consultations.

The texts of the published Latin documents were prepared in accordance with the guidelines created under the guidance of Władysław Semkowicz of the Polish Academy of Arts and Sciences (PAU) in 1924. (Instrukcja wydawnicza dla średniowiecznych źródet historycznych, red. Komisja Historyczna Polskiej Akademii Umiejętności przy współudziale Towarzystw Naukowych we Lwowie, Poznaniu, Warszawie i Wilnie, Archiwum Komisji Historycznej, Seria II, t. 2 [14], Kraków 1930: 1-40 [reprint: J. Tandecki, K. Kopiński, Edytorstwo źródet historycznych, Warszawa 2014: 311-327]). For the German texts, I followed Matthias Thumser (Zehn Thesen zur Editio deutschsprachiger Geschichtsquellen (14.-16. Jahrhundert), in: Editionwissenschaftliche Kolloquien 2005/2007. Methodik - Amtsbücher - Digitale Edition - Projekte, hrsg. von ibid., J. Tandecki unter Mitarbeit A. Thumser, Toruń 2008: 13-19). 
5 זולתי בשני ימים מוגבלים בשבועה שהם יום ג' ויום ו' יומי דשוקא וגם בימי היריד שהוא יא"ר מר"ק. ואותם

המשכונות

6 נמכור שנוכל להשבע עליהם שבועה דאוריתא על עשרת הדברות שהם שלנו. ואם יקרה שאיש או אשה בזדון

רוחו ילך ויש

7 מטלטלים לתוך העיר למוכרם חדשים או ישנים . וימצא שימכרם או שירצה למוכרם באזה יום שירצה שיהיה

זולתי בשני

8 הימים הנזכרים לעיל ובאי"ר מר"ק אז אנשי העיר רשאים לקחת כל מהטלטלים הנמצאים אצלו. ועוד היוד"י

ההוא יושם בתפיסה עד שיתן קנס לאדוננו הוויוודי ג' זקוקים. גם העבריות העניות יוכלו למכור בכל יום מצנפות

וענקים שהם

9 מעשה ידיהם ומלאכתם. והנה להיות האגרת הלז לעדות ולראייה ביד העירונים ואנשי העיר לעשות ולקים כל

הא

10 דלעיל בלי עורמה ובלי מרמה כתבנו וחתמנו

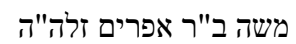

יעקב ב"ר אלכסנדרי הלוי ז"ל

יהושע ב"ר אפרים זלה"ה

מרדכי ב"ר יעקב ז"ל הי"ד

a word deleted by the scribe

[Translation]

1. We the undersigned elders of the sacred community of Krakow declare and proclaim, by signing [our names] in our own hand, that in agreement with all of the men of the kahal we have come to an understanding and willingly agree 2. without coercion, that we will not engage in any trade. We completely annul and abandon all matters of trade. We also cannot undertake any 3. trade or sales of goods to goyim. This does not include objects pawned with us, which we have held for a long time and which have been taken over to cover interest. We can 4 . sell in our own homes whenever the opportunity appears. But we will not be permitted to take these objects out to sell on the street and the market squares of the city 5. except for two specific days of the week, that is on Wednesdays and Fridays, which are market days, and on fair days. And these will be such pawned objects 6 . which we will sell, regarding which we can swear on the Torah on the Ten Commandments, that they belong to us. And should it happen that someone, be it a man or a woman, should 7. bring into the city new or old goods to sell, and it turns out that he or she is selling them with intent to sell on any day other than the two 8 . days mentioned above or during the yearly fair, then the councillors shall have the right to take the goods, that he or she has on him or her. In addition, the Jew shall be 9. arrested, until he pays a fine of three marcaerum to our lord the voivode. Poor Jewish women shall be permitted to sell caps and collars, that 10 . they have themselves made by hand. And so shall this document stand as proof and testimony in the hands of the councillors 
and burghers, that this which has been stated above, is binding without 11 . any excuse or evasion. Drawn up and signed by: Mosze son of Efraim, his memory for the world to come; Jaakow son of Alexander Halewi, his memory for the world to come; Jehoszua son of Efraim, his memory for the world to come; Mordechaj son of Jaakow, his memory for the world to come.

\section{2.}

[Krakow, June 1485]

The elders of the Krakow Kahal hereby declare in the name of the entire community, that henceforth the Krakow Jews will not participate in retail trade in the city, with the exception of selling unredeemed pawned property following strictly defined terms and conditions, and clothing accessories made by hand by poor women-Latin translation.

Sign.: ANK, MS no. 658/1250; paper card measuring: $213 \times 320 \mathrm{~mm}$; on the reverse in contemporary hand: Copia littere Judeorum in Latinum.

Copy: $A N K, M S$ no. 1449, f. 56v; in copy: Ipsum originale Haebraice scriptum extat in archivio in pixide laminea $\left(17^{\text {th }} \mathrm{c}\right.$.).

Pub.: Kodeks dyplomatyczny miasta Krakowa, part 1: 1257-1506, ed. F. Piekosiński, Monumenta Medii Aevi Historica Res Gestas Poloniae Illustrantia, vol. 5, Kraków 1879 (henceforth: KDMK 1), no. 192 (from the copy).

Transsumptum littere Judeorum Hebraice scripte.

Nos seniores Judei de Cracouia inferius notati recognoscimus / et testificamur cum sigillo manus nostre proprie, qualiter unanimi / voto tocius communitatis nostre consensimus et super nos recepimus / cum bona voluntate nostra absque omni coactione non mercari neque habere aliquas merces aut res mercatorias, sed illis renunciare et eas in toto dimittere. Eciam nullas merces aut res mercatorias recipere volumus a mercatoribus ad vendendum per manus nostras aliis Christianis, solummodo pignora nostra, que iam tempora impigneracionis persteterunt et in usuris deperierunt, talia vendere possumus in domibus nostris singulis temporibus, quando evenerit. Nec talia pignera portare audebimus ad negociandum vel vendendum in plateis aut in foris publicis in civitate vel circa civitatem, nisi in duobus diebus deputatis in septimana, videlicet feria tercia et feria sexta et in diebus nundinarum et illa pignora nos vendere debemus, super que iurare possumus ad Decem Precepta, quod nostra sunt. Et si contigerit, quod aliquis virorum vel mulierum presumptuose propria sponte deambulaverit et huiusmodi res ad vendendum deportaveit, sive sint nove sive veteres, et reperti fuerint, quod eas venderent vel vendere vellent. In quacunque die id fieret demptis prenotatis duobus diebus et nundinis, extunc incole civitatis facultatem habebunt illos vel illas recipere simul cum rebus, que apud eosdem reperte fuerint. Insuper talis Judeus vel Judea debet mitti ad carceres quousque dabit penam trium marcarum domino pallatino. Attamen Judei seu Judee pauperes poterint 
quolibet die vendere pepla et colloria, que sole operantur et laborant. Et hec littera erit in testimonium et documentum in manibus dominorum consulum et civium civitatis ad faciendum et confirmandum omnia superius expressa absque omni fraude et dolo. Hanc litteram scripsimus et sigillavimus nos hic infra scripti signanter: Moyses filius Effraym, Jacob filius Alexandri, Jozue filius Effraym, Mardocheus filius Jacob.

3.

[Krakow, June 1485]

The elders of the Kraków Kahal hereby declare in the name of the entire community, that henceforth the Kraków Jews will not participate in retail trade in the city, with the exception of selling unredeemed pawned property following strictly defined terms and conditions, and clothing accessories made by hand by poor women-German translation.

Sign.: ANK, MS no. 658/1251; paper card measuring: $312 \times 218 \mathrm{~mm}$; on the reverse in contemporary hand: Copia littere Judaice de verbo ad verbum ipsis interpretantibus scripta 92 in Almanico 1492.

Pub.: F.H. Wettstein, Mi-pinkase ha-kahal be-Kraka, p. II, n. (from the original).

Wir eldsten Juden von Crokaw undergesegelten bekennen und geczewgen mit zigel unserer hantschrifft, wy das mit eynykeit der ganczen / gemenen haben wyr vorwillet und haben entphangen uff uns unserem gutten willen an allen getwangk, nicht $\mathrm{zw}$ handeln und zw / haben mit keyner kawffmanschacz ader cremerey, dy solle wir vormeiden und lasen volkomlich. Auch sulle wyr nicht nemen kenerley koffmanschacz ader cremerey von kofflewten $\mathrm{zW}$ vorkauffen das durch unserer hant anderen cristen, nort unsere phande, dy do nw zynt vorstanden yr czeyt und zeyn verlorn ym wocher, dy mo ge wir vorkauffen yn unsern hewsern yn aller czeit, wenn zich ys fuget, und dy zelbige phande solle wyr nicht torren ummb tragen zw handeln und zw vorkauffen zy yn den gassen und uff den margkten yn der stat und czwusschen der stat north yn czwen gesaczten tagen yn der woche, das yst am dinstag und am freitagk und auch yn tagen des jormargktis, undt dy zelbigen phande zulle wyr vorkauffen, do uff wyr mo gen eyn eid thun uff dy czehen gebot, das zy unser zeyn und worde sych ys fogen, das eyn man ader ey fraw mit frewel zeines gemuttiis worde gen und worde ummbtragen gerethe czwusschen der stad zy czw vorkoffen new ader alt und worde gefunden, das her zy vorkaufft ader wolt vorkoffen an welchem tage das were an dy obgenante czwen tage und ym yormargkt, des zeyn dy statlewte geweldig, zy zw nemen mit alle den gerethen, dy bey $<$ yn $>$ gefunden worden und noch mer der zelbige Jude, der zal geleget werden yn dy gefengknes, bys das gibt 3 marg busse den herrn woywoden. Dy armen Juden dy mogen vorkauffen alle tage hawben und colner, dy zy zelbes arbeten und machen. Und dyzer briff zal zeyn czw geczewgnes und beweisunge yn dy hende der herren des rothes und lewte der stat, ZW thun und ZW bestetigen alles das do obgenent yst, an alle hinderlist habe wyr yn geschriben und gesigelt dy noch geschriben als nemlich: Moyses zon Effraym, Jocob zon Alexandri, Jozwe zon Effraym, Mardochey zon Jocob. 


\section{4.}

Krakow, 14 June 1485

Jan Amor of Tarnów, voivode of Kraków, endorses the resolutions taken by the elders of the Kraków Kahal in relation to the participation of Kraków's Jews in retail trade in the city.

Or.: ANK, MS no. 658/1248; document on paper measuring: $212 \times 237 \mathrm{~mm}$; below the text of the document, armorial seal of the issuer impressed through paper on a wax ground; on the reverse, in contemporary hand: Littera Judeorum; Littera Joannis Amor palatini Cracouiensis de mercatura Judeorum hic in Cracovia de data 1485.

Copy: ANK, MS no. 1449, k. 57r. $\left(17^{\text {th }}\right.$ c. $)$.

Pub.: KDMK 1, no. 193 (from copy).

Johannes Amor de Tharnow pallatinus Cracouiensis ${ }^{l}$ vigore presencium recognoscimus, / quomodo Judei Cracouienses dicioni et potestati nostri pallatinatus dediti et subiecti ad / nostram accedentes presenciam non nullos articulos, punctos et quasdam ordinaciones / et statuta videlicet videlicet $[s i c]$ infra scripta benivole, non coacti, civitati tenere et inviolabiliter observare compromiserunt. Primo, quia mercari non debent et omnes res mercatorias volunt et debent ommittere. Non debent neque volunt recipere a mercatoribus res aliquas mercatorias et easque vendere Christianis per manus eorundem quocumque nomine vocarentur, nisi ipsorum vadia propria, que ipsis invadiantur per Christianos et postea non exemuntur, sed apud ipsos manent et perduntur in usura, wlgariter vystoya sye. Item omnia possunt vendere, super que possunt iuramenta facere et docere iuramento, quod iam essent illorum propria, et eadem possunt vendere in domibus eorum temporum occurencium [sic]. Item eadem vadia non debent portare per civitatem vendentes, nisi in duobus diebus forensibus, videlicet feria tercia et feria sexta et in foro annuali et quicumque Judeorum seu Judearum portare vendendo per civitatem inveniretur seu arrestaretur, quod vellet vendere quascumque res sive novos sive veteres, demptis prefatis diebus forensibus et annuali foro, debent sibi recipi, et Judeus sive Judea debet castigari sessione et pena domino pallatino trium marcarum. Item Judei seu Judee pauperes debent et possunt vendere pepla et colleria, que sole laborent et operantur. Ut autem premisa habeant robur perpetue firmitatis sigillum nostrum iussimus presentibus imprimendum. Datum Cracouie feria tercia infra octavas Corporis Christi anno Domini millesimo quadringentesimo octuagesimo quinto.

${ }^{1}$ Jan Amor of Tarnów, voivode of Kraków in 1479-1490, see: Urzędnicy matopolscy XII-XV wieku. Spisy, ed. by J. Kurtyka, T. Nowakowski, F. Sikora, A. Sochacka, P.K. Wojciechowski, B. Wyrozumska; Urzędnicy dawnej Rzeczypospolitej XII-XVIII wieku. Spisy, ed. A. Gasiorowski, vol. 4, part 1, Wrocław-Warszawa-Kraków 1990: 130, no. 476. 